\title{
Review
}

\section{Carceral humanitarianism: Logics of refugee detention}

\author{
Kelly Oliver \\ University of Minnesota Press, Minneapolis, 2017, 1+84 pp., \\ ISBN: 978-1517903275
}

Contemporary Political Theory (2019) 18, S83-S86. https://doi.org/10.1057/s41296017-0178-z; published online 15 November 2017

Kelly Oliver's Carceral Humanitarianism: Logics of Refugee Detention is part of the University of Minnesota Press's Forerunners: Ideas First series, which publishes work that has been made public - at conferences or on blogs, for instance - but has not yet been formally published. The series makes new ideas available quickly. As is appropriate to the series, Oliver provides eleven chapters, an introduction and a conclusion, in a slim 84 pages that deconstruct the policies and practices of detainment that now constitute nation-states' main response to refugees. Given the project's aim to be both provocative and prospective, my review both touches on key points in the book and suggests directions for its development. Oliver's important analysis of humanitarianism, which she develops in conversation with Derrida's work, could be productively extended, I suggest, by expanding her attention to the first word of the title, carceral. As it is, the project risks relying on normative concerns about carcerality, while normalizing carceral practices more generally, ultimately undermining her critique. Further, Oliver could perform what remains in this book a call for an ethics of global interrelationality, by engaging with the theories and actions of those suffering the effects of carceral humanitarianism. ${ }^{1}$

In 'Rescue Politics,' Oliver discusses the scope of the political problem of carceral humanitarianism. She describes the terrible conditions that some of the world's 65 million refugees are subjected to in camps, which are purported to be generous havens from their war-torn countries. She uses numbers, but carefully clarifies hers is not a utilitarian argument, as though these conditions would be acceptable if fewer people were subjected to them. Rather, Oliver is pursuing vital ethical and political arguments for critiquing the form of humanitarianism at work in refugee camps. Thus, in addition to reviewing the overwhelming numbers of people fleeing violence, Oliver depicts the squalid conditions common in refugee camps, citing Panagiotis Kouroumblis, the Greek interior minister, referring to conditions in a Greek refugee camp as 'a modern-day Dachau' (p. 20). The

(c) 2017 Macmillan Publishers Ltd., part of Springer Nature. 1470-8914 Contemporary Political Theory Vol. 18, S2, S83-S86 www.palgrave.com/journals 
conditions of the camps, combined with the long periods - years and sometimes decades - of detention endured by people inhabiting them, is what prompts Oliver to call this humanitarianism carceral.

Oliver's deconstructive resistance to risk-benefit approaches to understanding and responding to refugees is served well by this setup. And it highlights the need for a clear concept of the carceral. Oliver notes that in the US: "refugees live in detention centers that look like and are run like prisons, with locked cells and "inmates" wearing jumpsuits, and where processing refugees takes months to years (Cone 2015). ... As in other prisons, conditions in detention centers are often poor, with inadequate health care, lack of facilities and personnel, and preventable deaths, including suicide (Granski, Keller, and Venters 2015)' (p. 21). The condemnation of these conditions as prison-like relies, of course, on prisons deserving condemnation. The argument seems to be that refugees should not be subjected to substandard healthcare, inadequate house, water, food, and services, preventable death including conditions that make suicide preferable to continuing to endure them, because if they have committed the crime of crossing a border illegally, then surely that is mitigated by the fact that they are fleeing war and persecution.

Perhaps Oliver intends a critique of prisons with this description, but if so, she does not offer one. For, again, it could be that the problem with carceral humanitarianism is its carcerality. That is, if refugees were not treated like prisoners resettled quickly with full political rights in a new country, for instance - then the problem of carceral humanitarianism is solved, but not the problem of detention more broadly. This implication is strengthened by Oliver's contrast, used to argue that carceral humanitarianism is a new development in the way refugees are treated, between the contemporary treatment of refugees, who 'may spend a significant portion of their lives in refugee camps,' and the treatment of refugees post World War II, who, Oliver notes, were resettled quickly (p. 4). Again, the problem appears to be with the detention of refugees, but not with the techniques of detention itself.

This is a real concern, as scholars focusing on the carceral have noted time and again, because there is a good reason to believe that extracting refugees from carceral logics cannot be accomplished through such a move. This inextricability is due, in part, with how people become recognized as refugees. Oliver offers a trenchant critique of this process, particularly its testimonial demands in 'Impossible Testimony.' There, Oliver describes the 'aporetic subject position' asylum seekers must occupy to become refugees, simultaneously attesting to their heroism, in escaping violence, and pathos, in having suffered mentally and physically at the hands of a power too great to endure (p. 33). Oliver notes that criminality is required to achieve this status, 'as national and international law requires that [the refugee] leave her home country and make her request for asylum on foreign soil, and usually do so as an illegal alien' (p. 28). Often, one must testify to refugee status from the position of a 'criminal.' That positioning of refugee seekers is one part of the imbrication of refugees and carcerality. 
Oliver's work points to another, perhaps more entangled aspect. She provocatively notes in her introduction that 'if we embraced radical democratic values, and had open borders, the very distinction between citizen and refugee would disappear as people moved freely across borders' (p. 11). What does an embracement of radical democratic values do to the distinction between citizen and criminal? Natalie Cisneros, for instance, has already offered a compelling analysis that immigrant detention and deportation not only share features of prisons (deportation centers look like prisons, and are sometimes former prisons, and the same private companies that run prisons in the US also run immigrant detention centers, for instance), but that both are techniques of racist normalization that aim at 'massive elimination' (Cisneros, 2016, pp. 242, 246). That is, both prisons and immigrant detention and deportation aim to eliminate not just people, but races of people, deemed threats to society because of their deviance, indicated by their criminal actions, including illegal border crossing (Cisneros, 2016, p. 246). My concern is that Oliver's notion of radical democracy, and earth ethics, which I will discuss below, remain toothless without explicit consideration of how racism operates to shore up state sovereignty in these different manifestations of carcerality.

The role of refugee detention in massive elimination could be connected to another diagnostic move Oliver makes, calling the current treatment of refugees 'A New Form of Genocide,' (which is the title of her penultimate chapter). She argues that the treatment of refugees amounts to genocide 'insofar as the refugees' living conditions in camps and detention centers are certainly lacking in personal security, liberty, health, and dignity and also too are often lacking in clean water, food and medical services, proper housing, clothing, and hygiene, and lead to sickness, disease, and death' (p. 72). Further, this subgroup of people is treated as fungible and disposable, the greater good of security for some justifying this exposure to death and sometimes outright murder of others. All of which can be said of prisons, in the US and elsewhere. Moreover, this line of critique is hardly novel. It not only can be said, but has been since at least the 1951 appeal to the United Nations by the Civil Rights Congress (CRC) titled: 'We Charge Genocide: The Historic Petition to the United Nations for Relief from a Crime of The United States Government Against the Negro People' (Civil Rights Congress, 1951; for a contemporary account of prisons as genocidal, see Whitehorn, 2014). Oliver's critique of sovereignty and citizenship could (and, I am suggesting, should) make productive connections to critiques of imprisonment as genocidal.

My final suggestion stems from the resonance of Oliver's rejection of a riskbenefit approach to human life with recent actions and statements by Deferred Action for Childhood Arrival (DACA) activists in the US. Activists, for instance, shouted down House Minority Leader Nancy Pelosi at a meeting in which she described working on a deal with the White House to pass the Dream Act, essentially making DACA law, in exchange for tighter boarder security. The activists drowned out Pelosi by shouting, 'We are not a bargaining chip!' (O’Keefe,

(c) 2017 Macmillan Publishers Ltd., part of Springer Nature. 1470-8914 Contemporary Political Theory Vol. 18, S2, S83-S86 S85 
2017). Oliver's rejection of such tit-for-tat approaches to human lives sheds light on the importance of this political action. Her analysis would be strengthened by engaging with the thoughts and actions of people who are directly affected. Such engagement seems called for by the ethical and political solutions Oliver sketches. In her conclusion, for instance, Oliver gestures toward an earth ethics, which 'requires us to begin to think of ourselves, and our relation to each other, beyond group or national identities and toward interrelationality determined by the interconnectedness of ecosystems and our biospheres. ... We need respond to others in ways that open up, rather than close down, the possibility of response' ( $\mathrm{p}$. 84). With refugee (and prisoner) writing, thoughts, and action more available for engagement and response than ever before, Oliver's project could enact her interrelational earth ethics to open up possibilities for responding to carceral humanitarianism through theorizing in conversation with the voices and actions of people on whose behalf she has so forcefully argued.

\section{Note}

1 I am grateful for conversations with Geoffrey Adelsberg, Andrew Dilts, and Carl Tyson that helped me hone my critical reading.

\section{References}

Cisneros, N. (2016). Resisting 'Massive Elimination': Foucault, Immigration, and the GIP. In Perry Zurn \& Andrew Dilts (Eds.), Active Intolerance: Michel Foucault, the Prisons Information Group, and the Future of Abolition (pp. 241-257). New York: Palgrave Macmillan.

Civil Rights Congress. 1951. We Charge Genocide: The Historic Petition to the United Nations for Relief From a Crime of The United States Government Against the Negro People. http://www.blackpast.org/ we-charge-genocide-historic-petition-united-nations-relief-crime-united-states-government-against.

O’Keefe, E. 2017. Nancy Pelosi Confronted by Immigration Rights Protesters About her DACA Talks with Trump. Washington Post. https:/www.washingtonpost.com/news/powerpost/wp/2017/09/18/nancypelosi-confronted-by-daca-recipients-protesting-her-agreement-with-trump/?utm_term=.6bafadc99c56.

Whitehorn, L. (2014). Black Power Incarcerated: Political Prisoners, Genocide, and the State. Socialism and Democracy 28(5): 101-117.

Sarah Tyson

University of Colorado Denver, Denver, CO 80204, USA sarah.k.tyson@ucdenver.edu 